\title{
Toxicity of a Mixture of Ten Metals to Phytoplankton*
}

\author{
W. H. Thomas ${ }^{1}$, J. T. Hollibaugh ${ }^{1}$, D. L. R. Seibert ${ }^{1}$ and G. T. Wallace, Jr. ${ }^{2}$ \\ ${ }^{1}$ Institute of Marine Resources, University of California, San Diego, La Jolla, California 92093, USA \\ ${ }^{2}$ Skidaway Institute of Oceanography, Savannah, Georgia 31406, USA
}

\begin{abstract}
We studied effects of a mixture of ten heavy metals ( $\mathrm{Cu}, \mathrm{Zn}, \mathrm{Ni}, \mathrm{Cr}, \mathrm{Pb}, \mathrm{Cd}, \mathrm{Hg}, \mathrm{As}, \mathrm{Sb}$ and $\mathrm{Se}$ ) on phytoplankton growth in a natural assemblage of diatoms and dinoflagellates from Saanich Inlet, B. C. (Canada) and in laboratory cultures of the diatom Thalassiosira aestivalis. Growth was not inhibited at metal concentrations expected to occur in a moderately polluted estuary. However, at 5- or 10-fold higher metal concentrations, phytoplankton growth was inhibited both in natural populations and in laboratory cultures. Inhibition of natural assemblages could be attributed to $\mathrm{Cu}$ and $\mathrm{Hg}$; deletion of these elements resulted in growth equivalent to that of control cultures containing no metals. Similarly, inhibition of $T$. aestivalis cultures was due to $\mathrm{Cu}$ in the metal mixture. With natural assemblages certain diatoms such as Chaetoceros sp., Rhizosolenia sp. or Nitzschia delicatissima were no longer dominant in cultures containing a metal mixture 5 times that in controls.
\end{abstract}

\section{INTRODUCTION}

There are many studies on single heavy metal ions affecting cultures or natural assemblages of phytoplankton. However, few workers have examined toxic effects of interactions of heavy metal ions. Effects of physiologically important cations on the toxicity of a heavy metal ion have been determined in several studies. Steemann-Nielsen et al. (1969) found that the toxicity of $\mathrm{Cu}$ to Chlorella pyrenoidosa was inversely related to $\mathrm{pH}$ and $\mathrm{K}^{+}$concentration; Harding and Whitton $(1976,1977)$ investigated the effects of $\mathrm{pH}, \mathrm{Mg}$ and $\mathrm{Ca}$ ions on the toxicity of $\mathrm{Zn}$ to Stigeoclonium tenue; and Braek, et al. (1976) reported that $\mathrm{Zn}$ toxicity to Phaeodactylum tricornutum was increased at low $\mathrm{Mg}$ ion concentrations. Studies of the effects of two or more heavy metals on phytoplankton populations are rare. However, in the discharge of industrial wastes, metals are usually added to the sea as mixtures. Krock and Mason (1971) found no consistent interaction between $\mathrm{Cu}$ and $\mathrm{Hg}$ added to San Francisco Bay phytoplankton. Jensen and co-workers have examined the effects of $\mathrm{Cu}$ and $\mathrm{Zn}$ on marine phytoplankton when the metals were added singly (Jensen et al., 1974, 1976) or in combination (Braek et al., 1976). The two metals acted synergistically on Amphidinium carterae, two clones of Skeletonema costatum and a clone of Thalassiosira pseudonana, but antagonistically on $P$. tricornutum.
Recently it has been demonstrated that the toxicity of copper is a function of the copper-free ion activity in the culture medium (Sunda and Guillard, 1976; Anderson and Morel, 1978; Jackson and Morgan, 1978; Morel et al., 1978; Sunda and Lewis, 1978). Most of these studies have been conducted in artificial seawater medium of known composition, $\mathrm{pH}$ and ionic strength. Free copper concentrations were controlled using either ethylenediaminetetraacetic acid (EDTA) or trishydroxymethylaminomethane (Tris) as metal-ion buffers; therefore, the response (growth, duration of log phase, motility) of phytoplankton could be studied relative to calculated copper activities. While this approach is useful in the laboratory, extrapolation to natural systems is currently impossible since the activity of copper in natural seawater cannot be determined directly; moreover, copper activity cannot be calculated, since the activities and conditional stability constants of organic ligands capable of interacting with copper are not known. The importance of the latter difficulty is emphasized by studies suggesting that copper binding organic ligands are present in sufficient quantities to effect the speciation of copper in seawater (Batley and Florence, 1976; Florence and Batley, 1976; Williams and Baldwin, 1976; Sugai and Healy, 1978). More specifically, the results of Sugai and Healy (1978) and Gillespie and Vaccaro (1978)

\footnotetext{
- Contribution from the Scripps Institute of Oceanography.
} 
indicate that dissolved organic matter in Saanich Inlet waters exerts a significant influence on the speciation of copper.

In view of the problems discussed above, we explored the toxicities of the mixture of metals and selected pairs of these metals in an empirical manner (a) to define the approximate concentration of the metal mixture inhibiting growth, and (b) to determine which metals in the mixture were primarily responsible for the inhibition. The results reported in this paper are an extension of our previous studies on the relative toxicities of metals added singly to phytoplankton from Saanich Inlet, B. C., Canada (Hollibaugh et al., 1980).

\section{MATERLALS AND METHODS}

The materials and methods employed in this study are essentially the same as those described in our earlier paper (Hollibaugh et al., 1980). The metals in the mixture were $\mathrm{Cu}, \mathrm{Zn}, \mathrm{Ni}, \mathrm{Cr}, \mathrm{Pb}, \mathrm{Cd}, \mathrm{Hg}, \mathrm{As}$, Se and $\mathrm{Sb}$. The concentrations of these metals reflected the higher concentrations found in an estuary moderately influenced by anthropogenic activity such as Narragansett Bay, Rhode Island, USA (Goldberg et al., 1977). Where data can be compared, the concentrations of some of the metals in Narragansett Bay often exceed those observed in Saanich Inlet, B. C. (Canada) by an order of magnitude (Table 1). Where data were not

Table 1. Comparison of trace metal concentrations in Narragansett Bay, RI, USA and Saanich Inlet, B. C., Canada

\begin{tabular}{|ccc|}
\hline Metal & $\begin{array}{c}\text { Narragansett Bay } \\
\text { (nM) }\end{array}$ & $\begin{array}{c}\text { Saanich Inlet } \\
\text { (nM) }\end{array}$ \\
\hline $\mathrm{Cu}$ & $9.4-52^{1,2}$ & $1.7-8.2^{5.6}$ \\
$\mathrm{Zn}$ & $28-133^{1}$ & $18^{6}$ \\
$\mathrm{Ni}$ & $43-272^{2.3}$ & $16^{6}$ \\
$\mathrm{~Pb}$ & $4-18^{2.3}$ & $0.5^{6}$ \\
$\mathrm{As}$ & $22^{4}$ & $16^{6}$ \\
& \\
${ }^{1}$ Piotrowicz (1977). \\
${ }^{2}$ Duce et al. (1972). \\
${ }^{3} \mathrm{E}$. W. Davey and P. E. Soper, unpublished. \\
${ }^{4}$ Ray and Johnson (1972). \\
${ }^{5} \mathrm{H}$. L. Windom, unpublished. \\
${ }^{6}$ G. T Wallace and R. G. Smith. unpublished. \\
\hline
\end{tabular}

available ( $\mathrm{Cd}, \mathrm{Cr}, \mathrm{Hg}$, Sb and Se), the concentrations selected for use in the metal mixture were approximately an order of magnitude above those reported to be representative of average seawater (Brewer, 1975). The concentrations of the multielement metal mixture (ME) given in Table 2 reflect these considerations.

The metals in the ME mix were made up as four solutions in the first experiment: $\mathrm{As}, \mathrm{Pb}$ and $\mathrm{Sb}$ were added separately, and all others were added from a combined stock solution $30 \mu \mathrm{M}$ in each metal. In all other cases the metals were added separately from $30 \mu \mathrm{M}$ stock solutions. Phytoplankton populations were exposed to ME mixtures ranging from 0.1 to 10.0 times the concentrations given in Table $2(0.1 \times \mathrm{ME}$ to $10.0 \times \mathrm{ME})$. Culture vessels were either 4-1 polyethylene Cubitainers (Cole Palmer Instrument Co., Chicago, Illinois, USA) or 0.25-l glass bottles. Prior work at Saanich Inlet indicated that such containers initially washed with hydrochloric acid and thorougly rinsed with deionized water did not leach enough metal to affect the present experiments, except possibly at the 0.1 and $0.5 \times$ concentrations. Adsorption of trace elements from solution onto container surfaces is a welldocumented phenomenon and may have influenced the results at the lower metal concentrations tested

Table 2. Composition of Multi-Element (ME) mix. Salinity was 29 to $30 \%, \mathrm{~N}$ as $\mathrm{NaNO}_{3}$, Si as $\mathrm{Na}_{2} \mathrm{SiO}_{3} \cdot 9 \mathrm{H}_{2} \mathrm{O}$, and $\mathrm{P}$ as $\mathrm{NaH}_{2} \mathrm{PO}_{4}$ were added from $10,10,1 \mathrm{mM}$ stock solutions as required

\begin{tabular}{|c|c|c|c|}
\hline \multirow[b]{2}{*}{ Metal } & \multirow[b]{2}{*}{ Compound } & \multicolumn{2}{|c|}{$\begin{array}{l}\text { Amount added to filtered } \\
\text { Saanich Inlet seawater }\end{array}$} \\
\hline & & $\mu \mathrm{gl}^{-1}$ & $\mathrm{nM}$ \\
\hline As V & $\mathrm{Na}_{2} \mathrm{HAsO}_{4}$ & 5.0 & 67 \\
\hline $\mathrm{Cd}$ & $\mathrm{CdCl}_{2}$ & 0.75 & 6.7 \\
\hline $\mathrm{Cr}$ & $\mathrm{K}_{2} \mathrm{Cr}_{2} \mathrm{O}_{7}$ & 3.0 & 58 \\
\hline $\mathrm{Cu}$ & $\mathrm{CuSO}_{4} \cdot 5 \mathrm{H}_{2} \mathrm{O}$ & 3,0 & 47 \\
\hline $\mathrm{Hg}$ & $\mathrm{HgCl}_{2}$ & 0.15 & 0.75 \\
\hline $\mathrm{Ni}$ & $\mathrm{NiCl}_{2}$ & 5.0 & 85 \\
\hline $\mathrm{Pb}$ & $\mathrm{PbCl}_{2}$ & 3.0 & 14 \\
\hline $\mathrm{Sb}$ & $\mathrm{K}(\mathrm{SbO}) \mathrm{C}_{4} \mathrm{H}_{4} \mathrm{O}_{6} \cdot 1 / 2 \mathrm{H}_{2} \mathrm{O}$ & 1.5 & 12.3 \\
\hline Se & $\mathrm{SeO}_{2}$ & 1.5 & 19 \\
\hline $\mathrm{Zn}$ & $\mathrm{ZnCl}_{2}$ & 5.0 & 76 \\
\hline
\end{tabular}

(Robertson, 1968; Subramanian et al., 1978). Daily measurement of the concentration of each metal in each container was logistically impossible.

Water and phytoplankton were collected from CEE 77-2 (CEE: Controlled Experimental Ecosystem, Menzel and Case, 1977) on 8 June 1977. The CEE was initiated five weeks earlier as part of another experiment. Nutrients ( $N, \mathrm{Si}$ and $\mathrm{P}$ ) had been added on 7 June and at this time the water column had been thoroughly mixed by bubbling with air. An integrated 0-16 m sample was collected by pumping and was taken to the laboratory. The experiment was performed in 4-1 plastic Cubitainers and five varying concentrations of the multielement metal mixture (ME) were tested.

The 4-I samples were incubated outdoors in a water bath kept at a constant temperature $\left(11^{\circ} \mathrm{C}\right)$. Natural sunlight was attenuated by covering the entire water 
table with a translucent plastic tarp. The $0.25-1$ samples were incubated in a $12^{\circ} \mathrm{C}$ cold room on a $17 / 7 \mathrm{~L} / \mathrm{D}$ cycle at $120 \mu \mathrm{Em}^{-2} \mathrm{~s}^{-1}$ illumination from cool white fluorescent lights. When the water was collected, larger zooplankton were removed by filtration of the seawater through a $200 \mu \mathrm{m}$ mesh net.

Growth was generally measured by in vivo chorophyll fluorescence at daily intervals. We recognize that fluorescence inhibition may be due to metal stress rather than an inhibition of growth, but fluorescence growth measurements gave the same results as growth measured by microscopic cell counts (compare Figs 1 and 2).

Cell counts were made using a Zeiss inverted microscope. Diversity indices, similarity indices, and cell carbon were calculated from cell counts as described in Thomas et al. (1977). Thalassiosira aestivalis (Gran and Angst, 1931) was isolated by D.L.R.S. from an enrichment culture of Saanich Inlet phytoplankton.

\section{RESULTS}

\section{Natural Phytoplankton Populations}

Phytoplankton species and nutrient concentrations of the initial water sample for the first experiment are given in Table 3. A pronounced decline in phytoplankton standing crop was observed during the first $2 \mathrm{~d}$ of this experiment. After recovery, a toxic effect was not observed in samples with less than a concentration five times $(5 \times \mathrm{ME})$ that of the original mixture (Fig. 1).

Table 3. Initial species composition of phytoplankton sample for Experiment I from CEE 77-2

\begin{tabular}{|cc|}
\hline \multicolumn{1}{|c|}{ Species } & \% by Carbon \\
\hline Chaetoceros spp. & 14 \\
Corethron criophilum & 1 \\
Coscinodiscus spp. & 2 \\
Leptocylindrus danicus & 4 \\
Thalassiosira spp. & 2 \\
Licmophora abbreviata & 1 \\
Amphidinium spp. & 11 \\
Exuviella spp. & 6 \\
Gymnodinium spp. & 6 \\
Gyrodinium spp. & 34 \\
Peridinium spp. & 3 \\
Unidentified microflagellates & 8 \\
Other species & 6 \\
Total & 100 \\
${\text { Nutrients }\left(\mu \mathrm{l}-\mathrm{at} \mathrm{l}^{-1} \text { ) }\right.}_{\mathrm{NO}_{3}-\mathrm{N}}$ & \\
$\mathrm{NH}_{3}-\mathrm{N}$ & 5.7 \\
$\mathrm{SiO}_{4}$-Si & 1.2 \\
$\mathrm{PO}_{4}-\mathrm{P}$ & 0.9 \\
\hline
\end{tabular}

Some stimulation of growth took place at the $0.5 \times \mathrm{ME}$, and $1.0 \times \mathrm{ME}$ concentrations, and there was no growth at $10.0 \times \mathrm{ME}$. At the end of the experiment all samples were examined for phytoplankton species composition.

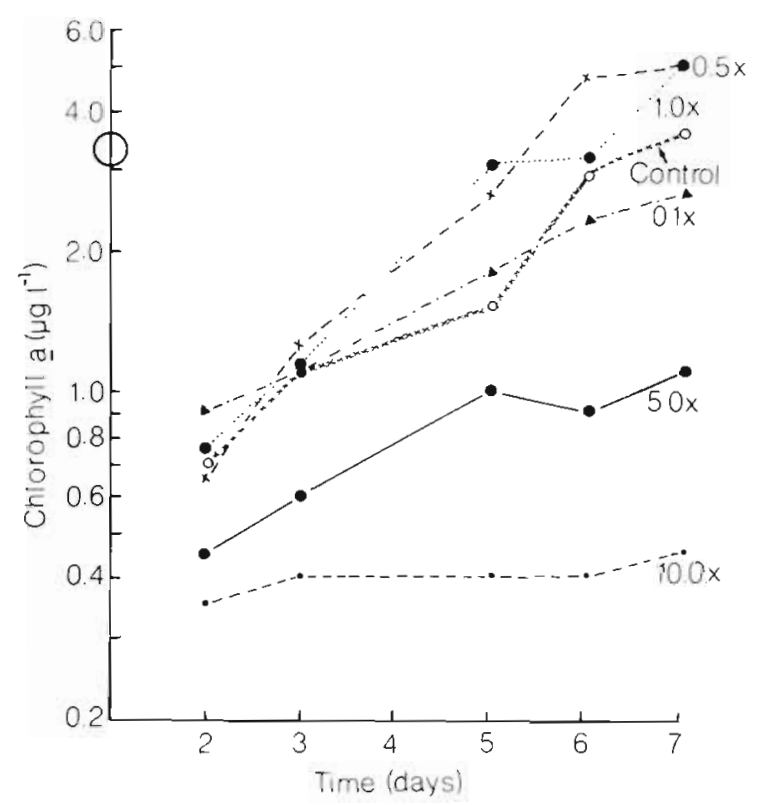

Fig. 1 Growth of natural phytoplankton assemblages from CEE 77-2 in varying concentrations of multielement (ME) mixture. Circle on ordinate: Day 0 values
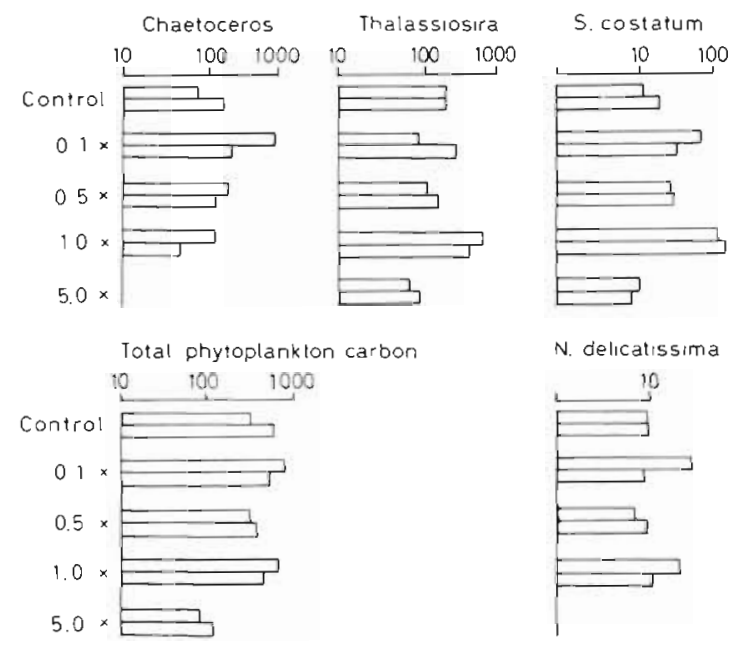

Fig. 2. Species composition expressed as carbon $\left(\mu \mathrm{g} \mathrm{Cl}^{-1}\right)$, of phytoplankton assemblages from CEE $77-2$ after growth for 8 $\mathrm{d}$ in the presence of varying concentrations of the ME mix. Chaetoceros spp. and Nitzschia delicatissima were not present at $5.0 \times$ ME. Paired bars indicate abundances in duplicated experiments

Although the initial water sample in this first experiment was dominated by a dinoflagellate population (Table 3), four diatom taxa dominated on the eighth day (Fig. 2). The stimulation of growth at the $1.0 \times \mathrm{ME}$ 
concentration resulted in increased standing crops of Thalassiosira sp. and Skeletonema costatum. The increase of growth in the $0.5 \times \mathrm{ME}$ treatment was not evident from the phytoplankton carbon or cell number data. Nitzschia delicatissima and Chaetoceros sp. were not present in the $5.0 \times \mathrm{ME}$ cultures; other taxa, not included in Figure 2, were also inhibited at this concentration and Thalassiosira sp. and $S$. costatum together represented nearly $100 \%$ of the standing stock on Day 8.

The next experiment tested the hypothesis that the effects of the ME mix were due primarily to the $\mathrm{Cu}$ and $\mathrm{Hg}$ that it contained, rather than to the total metal load. A comparison of the relative toxicities of the metals in the ME mix to their relative concentrations in the ME mix suggested that $\mathrm{Cu}$ and $\mathrm{Hg}$ would reach a toxic concentration before the rest of the metals (Hollibaugh et al., 1980). Cu should become toxic at about $5 \times \mathrm{ME}$ $(\mathrm{Cu}=235 \mathrm{nM})$ if all of the metals in the ME mix were assumed to act independently. In addition, distinctive morphological aberrations (clumps of daughter cells failing to separate after division and elongated, out-ofcolumn frustules) were observed previously in Thalassiosira aestivalis grown at $5 \times \mathrm{ME}$ (Thomas et al. 1980). The same type of aberration had been observed consistently when $T$. aestivalis was grown in medium to which 100 to $500 \mathrm{nM}$ of $\mathrm{Cu}$ had been added. All of this evidence suggested that the toxicity of the ME mix might be directly related to its $\mathrm{Cu}$ and $\mathrm{Hg}$ content.

Accordingly, the toxicities of $\mathrm{Cu}$, the $\mathrm{ME}$ mix, the $\mathrm{ME}$ mix with $\mathrm{Cu}$ deleted (ME minus $\mathrm{Cu}$ ), ME minus $\mathrm{Hg}$, and $\mathrm{ME}$ minus both $\mathrm{Cu}$ and $\mathrm{Hg}$ were compared in a second experiment. The phytoplankton assemblage was collected at Station 77-1 in Saanich Inlet $\left(48^{\circ} 39.6^{\prime} \mathrm{N}, 123^{\circ} 29.6^{\prime} \mathrm{W}\right)$ on 14 September, 1977. Nutrients were added to the phytoplankton assemblage to give initial nutrient concentrations of 10.1,20.5, and $1.7 \mu \mathrm{g}$-at $\mathrm{l}^{-1}$ for $\mathrm{N}, \mathrm{Si}$, and $\mathrm{P}$., respectively. Growth curves (Fig. 3) suggested that toxicity was determined primarily by the $\mathrm{Cu}$ and $\mathrm{Hg}$ in the $5 \times \mathrm{ME}$ mix. Growth of the phytoplankton was slightly improved when $\mathrm{Hg}$ was deleted from the mixture, but a much greater improvement was seen when $\mathrm{Cu}$ was deleted. The best growth was obtained when both $\mathrm{Cu}$ and $\mathrm{Hg}$ were deleted; $5.0 \times$ and $10.0 \times \mathrm{ME}$ minus both $\mathrm{Cu}$ and $\mathrm{Hg}$ improved phytoplankton yield at the end of the log growth phase by 4.4 and 4.3 times over the control growth yield and greatly decreased the lag time. At these concentrations of the complete $\mathrm{ME}$ mix with $\mathrm{Cu}$ and $\mathrm{Hg}$, growth yield was only 0.2 to 0.4 of the control, and the populations did not recover from their initial decline. The $5.0 \times$ and $10.0 \times \mathrm{ME}$ minus $\mathrm{Cu}$ showed improved growth yields and decreased lag times compared to the ME mix, while $10.0 \times \mathrm{ME}$ minus $\mathrm{Hg}$ did
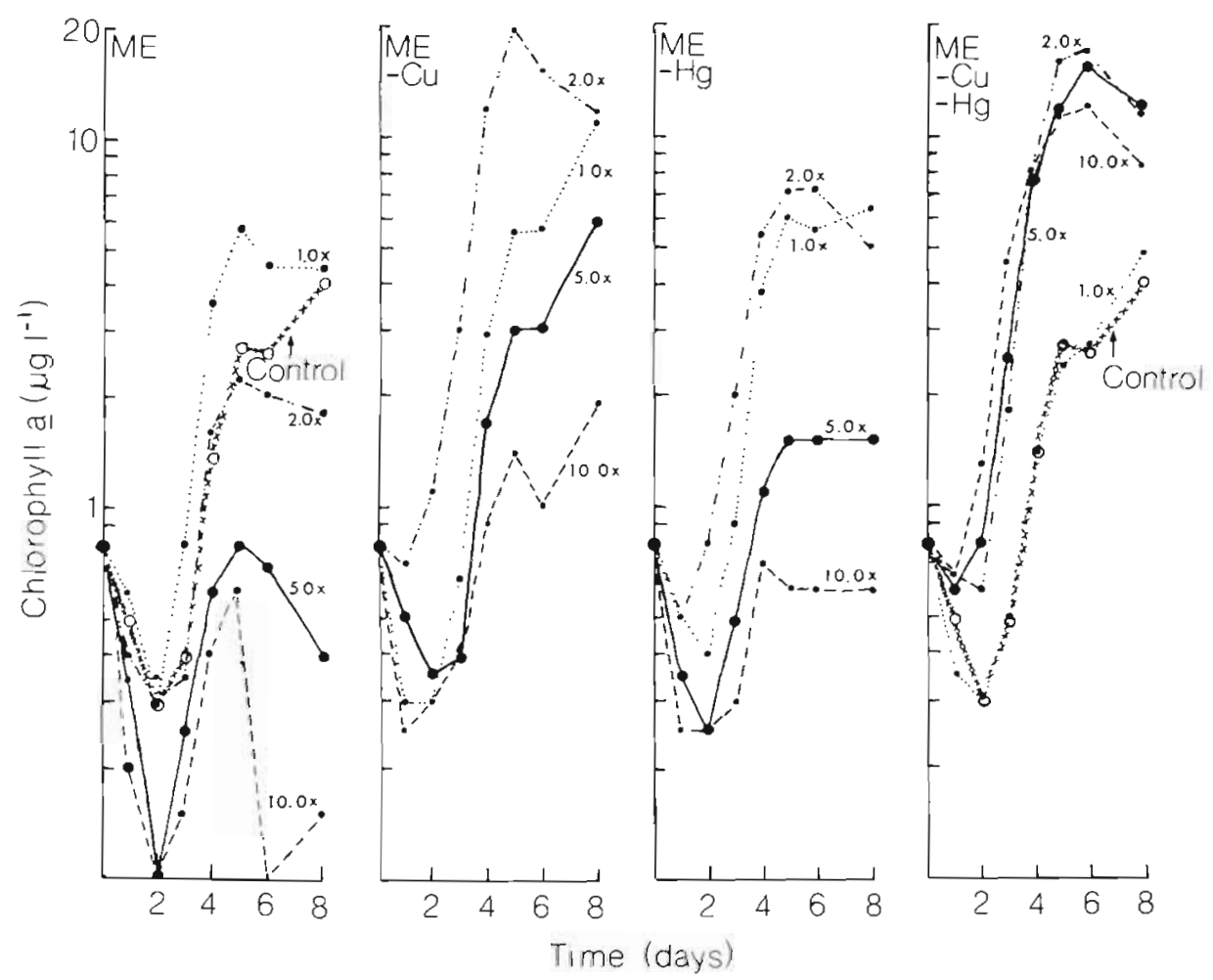

Fig. 3. Growth of natural phytoplankton assemblages exposed to varying concentrations of ME mix, ME mix with Cu deleted (ME minus $\mathrm{Cu}$ ), $\mathrm{ME}$ minus $\mathrm{Hg}$, and $\mathrm{ME}$ minus both $\mathrm{Hg}$ and $\mathrm{Cu}$. Growth of controls shown in right- and left-hand panels only 


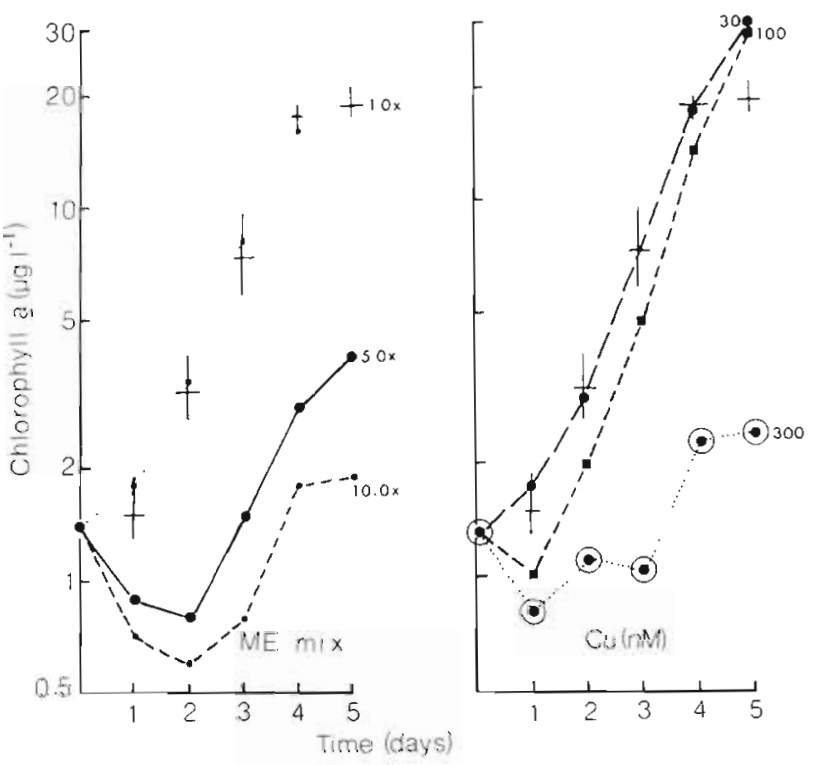

Fig. 4. Growth of a natural phytoplankton assemblage contained in glass bottles and exposed to varying concentrations of $\mathrm{ME}$ mix and $\mathrm{Cu}$. Cu concentration expressed in nM. Crosses: range and mean of 3 controls not recover from the initial decline and growth yields at both $5.0 \times$ and $10.0 \times \mathrm{ME}$ minus $\mathrm{Hg}$ were only slightly greater than those of the complete ME mix at these concentrations.

The cell carbon of the initial assemblage in this second experiment was dominated by the centric diatoms Chaetoceros sp., Melosira sp., and Skeletonema sp. with some small percentages of the dinoflagellates Gymnodinium sp. and Peridinium sp. At the end of the experiment some of the treatments were examined microscopically to determine if any species shifts had occurred. The control culture (no metal additions) contained the same centric diatoms as those found initially and also Rhizosolenia sp. In the $5.0 \times \mathrm{ME}$ culture Chaetoceros sp. and Rhizosolenia sp. were no longer dominant and most of the assemblage was made up of the centric diatoms Skeletonema sp. and Thalassiosira sp. When $\mathrm{Cu}$ and/or $\mathrm{Hg}$ were deleted from the metal mix, the assemblage was similar to that of the control; Chaetoceros sp. and Rhizosolenia sp. were again dominant along with Skeletonema sp. and Thalassiosira sp. Species diversity indices (Shannon and Weaver, 1963) in the
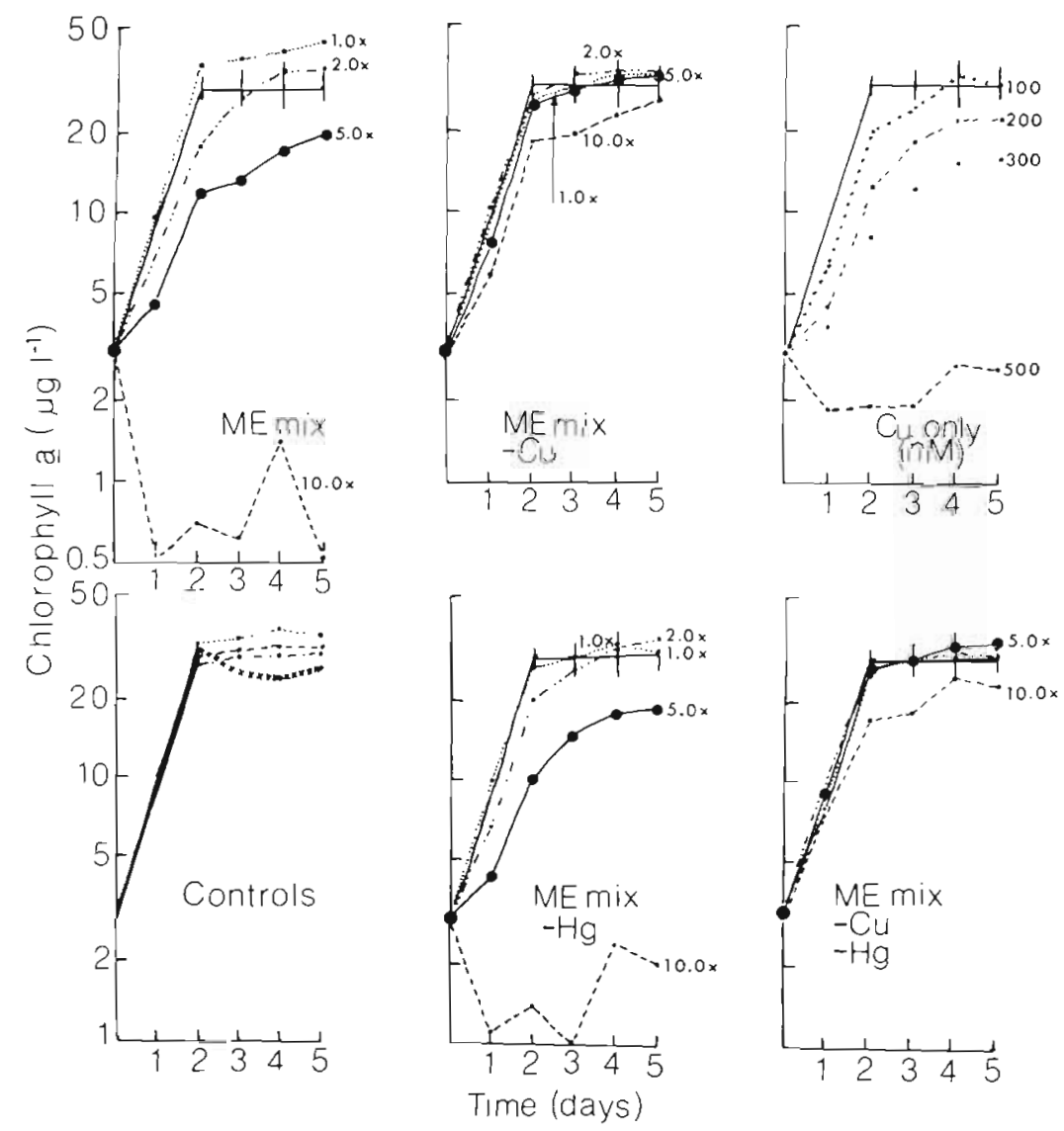

Fig. 5. Thalassiosira aestivalis. Growth in varying concentrations of ME mix (ME minus Cu, ME minus Hg, ME minus both Hg and $\mathrm{Cu}$ ) and $\mathrm{Cu}$. $\mathrm{Cu}$ concentration in $\mathrm{nM}$ 
treated cultures did not differ greatly from the control. In all the treated cultures, except $5.0 \times \mathrm{ME}$, the similarity index (Whittaker, 1960) was $>80 \%$ of that of the control. In the $5.0 \times \mathrm{ME}$ culture the similarity was $72 \%$ of the control. This reflects the decrease in dominance of Chaetoceros sp. and Rhizosolenia sp. Total phytoplankton carbon concentrations in the $5.0 \times \mathrm{ME}$ and $5.0 \times \mathrm{ME}$ minus $\mathrm{Cu}$ treatments $(419$ and $243 \mu \mathrm{gC} \mathrm{l}^{-1}$ respectively) were lower than those of the control (991 $\left.\mu \mathrm{gC} \mathrm{l}^{-1}\right)$ at the end of the experiment. In all other treatments final phytoplankton carbon concentrations were greater than that in the control. This compares favorably with the results for in vivo fluorescence given in Figure 3.

As part of this experiment, we incubated the natural assemblage at $1.0 \times, 5.0 \times$, and $10.0 \times \mathrm{ME}$ in $0.25-1$ glass bottles at $12{ }^{\circ} \mathrm{C}$ to see if changes in container material and size (surface to volume ratio) might affect the results. In glass bottles we also found inhibition at $5.0 \times$ and $10.0 \times \mathrm{ME}$ as compared with the control and $1.0 \times$. Thus the container material and surface to volume ratio did not seem to have an effect on metal mixture toxicity. These results are shown in Figure 4.

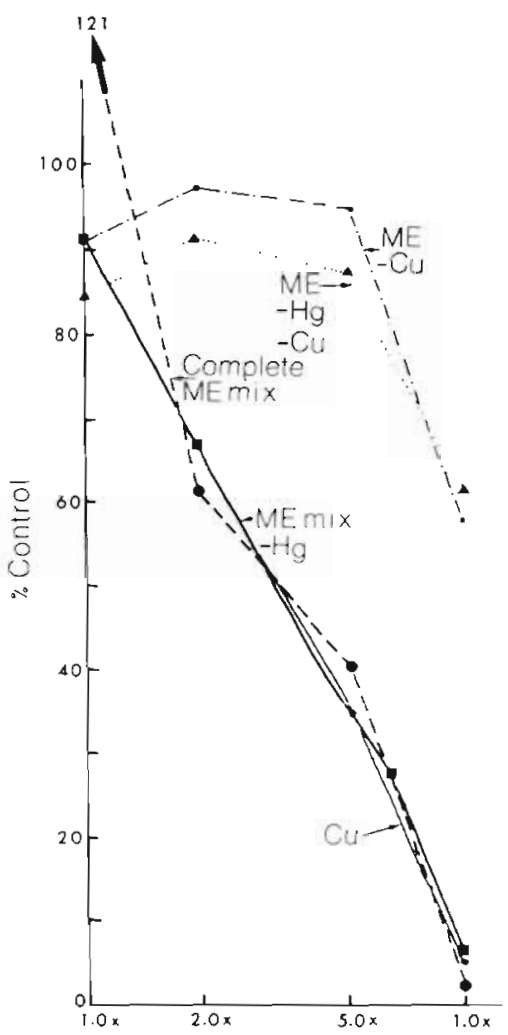

Fig. 6. Thalassiosira aestivalis. Growth in varying concentrations of $\mathrm{ME}$ mix (ME minus $\mathrm{Cu}$, $\mathrm{ME}$ minus $\mathrm{Hg}$, $\mathrm{ME}$ minus both $\mathrm{Hg}$ and $\mathrm{Cu}$ ) and $\mathrm{Cu}$, expressed as percent of growth attained by controls at end of logarithmic growth phase (Day 2). Cu plotted as multiples of its concentration in complete ME mix

\section{Thalassiosira aestivalis}

Although the two experiments with natural assemblages gave comparable results in that centric diatoms were the dominant algae at the end of the experiments, natural assemblages can differ in their species composition. Therefore we isolated a representative diatom, Thalassiosira aestivalis, and repeated the experiments. The cultures were incubated in glass bottles in the cold room. Figure 5 shows growth curves of $T$, aestivalis with metal mixtures (ME), ME minus $\mathrm{Cu}_{1} \mathrm{ME}$ minus $\mathrm{Hg}$, and $\mathrm{ME}$ minus both $\mathrm{Cu}$ and $\mathrm{Hg}$. $\mathrm{A}$ set of treatments with $\mathrm{Cu}$ alone at several concentrations was also included.

Most of the toxicity of the ME mixture was due to the $\mathrm{Cu}$ it contained. The removal of $\mathrm{Hg}$ still resulted in some toxicity at $5.0 \times \mathrm{ME}$ and $10.0 \times \mathrm{ME}$. Growth of the samples is expressed as a percentage of the growth of the controls at the end of the exponential growth phase (Fig. 6). This demonstrates that the inhibition of the ME mixture was definitely due to $\mathrm{Cu}$ although 10.0 $\times$ ME minus $\mathrm{Cu}$ or $10.0 \times$ ME minus both $\mathrm{Cu}$ and $\mathrm{Hg}$ were somewhat toxic. These results are comparable to those found with ME mixtures and natural assemblages (Fig. 3).

\section{DISCUSSION}

Discharge of metals into the sea exerts complex effects on phytoplankton. Metals are usually discharged as mixtures, and each metal has a different relative toxicity. Hollibaugh et al. (1980) have shown that $\mathrm{Hg}$ and $\mathrm{Cu}$ are the most toxic of ten metals tested singly. Also, metals can affect different species of phytoplankton according to the relative susceptibility of each species. Finally, metals may have synergistic effects. Thus, the effect due to mixtures of metals may be greater than the effect of each metal alone. In the experiments described here we have investigated some of these complexities.

Mixtures of metals at concentrations that approximate conditions in a moderately polluted estuary (Narragansett Bay) were generally without demonstrable effect on natural assemblages or Thalassiosira aestivalis. However, when concentrations increased 5 - or 10-fold, the mixture inhibited growth. In natural assemblages, the toxicity of these mixtures was due to $\mathrm{Cu}$ and $\mathrm{Hg}$ in the mixture. With $\mathrm{T}$. aestivalis, toxicity was due to $\mathrm{Cu}$. That is, when these metals were deleted from the mixture, the algae grew as well as those in control cultures to which no metals were added.

While overall growth of natural assemblages was reduced by $5.0 \times M E$, the most striking effect was the 
elimination of the centric diatoms Chaetoceros sp. and Rhizosolenia sp., and the pennate diatom Nitzschia delicatissima as dominant organisms. Deletion of $\mathrm{Cu}$ and/or $\mathrm{Hg}$ from $5.0 \times \mathrm{ME}$ restored the dominance of Chaetoceros sp., and Rhizosolenia sp. Skeletonema sp. and Thalassiosira sp. retained dominance in all treatments. General species diversity did not change much upon treatment with $5.0 \times \mathrm{ME}$ as compared to the control, but species similarity to the control was reduced.

We made some preliminary experiments on the effects of Cu-Zn pairs, Cu-Ni pairs, and Cu-Cd pairs of metals on Thalassiosira aestivalis to test for synergistic or antagonistic effects (unpublished). In one experiment there was no additive toxicity between $\mathrm{Cu}$ and $\mathrm{Zn}$, but in another there was an additive effect with these two metals. Cu-Ni pairs and $\mathrm{Cu}-\mathrm{Cd}$ pairs showed an additive effect in one experiment. However, these results are not considered conclusive. The algae were only grown for $3 \mathrm{~d}$ in each experiment and such results deserve more extensive investigation, which was not possible during our stay at the Saanich Inlet laboratory. Braek et al. (1976) demonstrated synergistic effects between $\mathrm{Cu}$ and $\mathrm{Zn}$ with three species of phytoplankton in cultures, but found antagonism between the two metals with another species. Synergism could be due to preferential binding of a less toxic over a more toxic ion by protein constituents within the cells, thus potentially raising the intracellular activity of the more toxic metal. Synergism could also arise extracellularly when metals less toxic than $\mathrm{Cu}$ are able to displace $\mathrm{Cu}$ from inorganic or organic ligands occurring in seawater and thus increase the free ion activity of copper. It has recently been demonstrated that $\mathrm{Cu}^{2+}$ ion activities rather than concentrations, determine $\mathrm{Cu}$ toxicities (Sunda and Guillard, 1976; Anderson and Morel, 1978; Morel et al., 1978).

Lack of definition of the chemical nature and total concentration of the metal species in these experiments necessarily impose some degree of uncertainty on the interpretation of the results. The activities of the free metal ions reflect complex equilibria with the surface of the culture vessel and with organic and inorganic ligands present in the seawater medium. The data necessary to compute the speciation and the techniques necessary to verify the calculated free ion activities of the metals in these experiments are not yet available. However, we feel the empirical approach applied here is useful in identifying the relative toxicity of various trace metals in natural waters where the identity and concentration of potentially important organic ligands are still unknown. Such an approach can also show which metals are most likely to produce synergistic or antagonistic effects and can focus attention on the most critical elements in the matrix.
Despite these uncertainties, we conclude that concentrations less than 5 times those in the original metal mix (designed to simulate trace metal concentrations in a moderately polluted estuary) can significantly inhibit the growth of natural phytoplankton assemblages. Most of the inhibition is attributed to the presence of copper and mercury in the metal mixture.

Acknowledgements. The authors would like to express their gratitude to the staff of the CEPEX laboratory at Patricia Bay, B. C. (Canada), and in particular to R. Brown, for their help during the 1977 field season. Dr. R. W. Eppley kindly reviewed the manuscript. This study was funded by NSF Grants OCE 76-22139 and OCE 76-22717.

\section{LITERATURE CITED}

Anderson, D. M., Morel, F. M. M. (1978). Copper sensitivity of Gonyaulax tamarensis. Limnol. Oceanogr. 23: 283-295

Batley, G. E., Florence, T. M. (1976). Determination of the chemical forms of dissolved cadmium, lead and copper in seawater. Mar. Chem. 4: 347-363

Braek, G. S., Jensen, A., Mohus, A. (1976). Heavy metal tolerance of marine phytoplankton. III. Combined effects of copper and zinc ions on cultures of four common species. J. exp. mar. Biol. Ecol. 25: 37-50

Brewer, P. G. (1975). Minor elements in seawater. In: Riley, J. P., Skirrow, G. (eds) Chemical oceanography, Vol. 1. Academic Press, San Francisco, pp. 415-496

Duce, R. A., Quinn, J. G., Olney, C. E., Piotrowicz, S. R., Ray, B. J., Wade, T. L. (1972). Enrichment of heavy metals and organic compounds in the surface microlayer of Narragansett Bay, Rhode Island. Science, N. Y. 176: 161-163

Florence, T. M., Batley, G. E. (1976). Trace metal species in seawater. I. Removal of trace metals from sea-water by a chelating resin. Talanta 23: 179-186

Gillespie, T M., Vaccaro, R. F. (1978). A bacterial bioassay for measuring the copper chelation capacity of seawater. Limnol. Oceanogr. 23: 543-548

Goldberg, E. D., Gamble, E., Griffin, J. J., Koide, M. (1977). Pollution history of Narragansett Bay as recorded in its sediments. Estuar, Coast. Mar. Sci. 5: 549-561

Gran, H. H., Angst, E. C. (1931). Plankton diatoms of Puget Sound. Publ. Puget Sound Mar. Biol. Stud. 7: 417-516

Harding, J. P. C., Whitton, B. A. (1976). Resistance to zinc of Stigeoclonium tenue in the field and the laboratory. $\mathrm{Br}$. Phycol. J. 11: 417-426

Harding, J. P. C., Whitton, B. A. (1977). Environmental factors reducing the toxicity of zinc to Stigeoclonium tenue. $\mathrm{Br}$. Phycol. J. 12: 17-21

Hollibaugh, J. T., Seibert, D. L. R., Thomas, W. H. (1980). A comparison of the acute toxicity of ten heavy metals to phytoplankton from Saanich Inlet, B. C., Canada. Estuar Coast. Mar. Sci. (in press)

Jackson, G. A., Morgan, J. J. (1978). Trace metal - chelator interactions and phytoplankton growth in seawater media: Theoretical analysis and comparison with reported observations. Limnol. Oceanogr. 23; 268-282

Jensen, A., Rystad, B., Melsom, S. (1974). Heavy metal tolerance of marine phytoplankton. I. The tolerance of three algal species to zinc in coastal sea water. J. exp. mar. Biol. Ecol. 15: 145-147

Jensen, A., Rystad, B., Melsom, S. (1976). Heavy metal tolerance of marine phytoplankton. II. The copper tolerance of 
three species in dialysis and batch assays. J. exp. mar. Biol. Ecol. 22: 249-256

Krock, H. J., Mason, D. T. (1971). Bioassays of lower trophic levels. A study of toxicity and biostimulation in San Francisco Bay - Delta Waters. San. Eng. Res. Lab., Univ. of Calif., Berkeley Rept. No. 71-86

Menzel, D. W. Case, J. (1977). Concept and design: Controlled ecosystem pollution experiment. Bull. Mar. Sci. 27: 1-7

Morel, N. M. L., Reuter, J. G., Morel, F. M. M. (1978). Copper toxicity to Skeletonema costatum. J. Phycol. 14: 43-48

Piotrowicz, S. R. (1977). Studies of the sea to air transport of trace metals in Narragansett Bay, $\mathrm{Ph} . \mathrm{D}$. thesis, University of Rhode Island

Ray, B. J., Johnson, D. L. (1972). A method for the neutron activation analysis of natural waters for arsenic. Analytica chim. Acta 62: 196-199

Robertson, D. E. (1968). The absorption of trace elements in sea water on various container surfaces. Analytica chim. Acta 42: 533-536

Shannon, C. E., Weaver, W. (1963). The mathematical theory of communication, University of Illinois Press, Chicago

Steemann-Nielsen, E., Kamp-Nielsen, L., Wium-Andersen, S. (1969). The effect of deleterious concentrations of $\mathrm{Cu}$ on the photosynthesis of Chlorella pyrenoidosa. Physiolgia Pl. 22: 1121-1133
Subramanian, K. S., Chakrabarti, C. L., Sueiras, J. E., Maines, I. S. (1978). Preservation of some trace metals in samples of natural waters. Analyt. Chem. 50: 444-448

Sugai, S. F., Healy, M. L. (1978). Voltammetric studies of the organic association of copper and lead in two Canadian inlets. Mar. Chem. 6: 291-308

Sunda, W., Guillard, R. R. L. (1976). The relationship between cupric ion activity and the toxicity of copper to phytoplankton. J. Mar Res. 34: 511-529

Sunda, W. G., Lewis, J. M. (1978). Effect of complexation by natural organic ligands on the toxicity of copper to a unicellular alga, Monochrysis lutheri. Limnol. Oceanogr. 23: $870-876$

Thomas, W. H., Seibert, D. L. R., Takahashi, M. (1977). Controlled ecosystem pollution experiment: Effect of mercury on enclosed water columns. III. Phytoplankton population dynamics and production. Mar Sci. Comm. 3: 331-354

Thomas, W. H., Hollibaugh, J. T., Seibert, D. L. R. (1980). Effects of heavy metals on the morphology of some marine phytoplankton. Phycologia (in press)

Whittaker, R. H. (1960). Vegetation of the Siskiyou Mountains, Oregon and California. Ecol. Monogr. 30: 279-338

Williams, P. M., Baldwin, R. J. (1976). Cupric ion activity in coastal seawater. Mar. Sci. Comm. 2: 161-181

This paper was presented by Dr. N. D. Holland; it was accepted for printing on January 12, 1980. 